\title{
Effects of Employment and Social Protection Reforms in Spain: a jurisprudential perspective
}

\author{
Eduardo López Ahumada \\ Lecturer in Labour and Social Security Law (PhD) \\ University of Alcalá (Spain)
}

Recibido: 09.05.2016

Aceptado: 09.06.2016

DOI: http://dx.doi.org/10.20318/sllerj.2016.3309

\begin{abstract}
This paper analyzes the consequences of the process of labor reforms on the Spanish labor market. Specifically, it is deepened in the interpretation of the social courts of the reforms related to employment and social protection. Therefore, the main legal measures during times of crisis are studied, which have introduced an important space to labour flexicurity. Highlighting the changes related to internal flexibility and external that have been interpreted and sometimes corrected by social jurisprudence.
\end{abstract}

Keywords: labour reforms, Spanish labor market, social jurisprudence, labour flexicurity, internal flexibility, external flexibility.

\section{Objective and purpose of reforming the Spanish job market}

Since May 2010, Spanish labour legislation has suffered a profound change derived from economic and social policy promoted by Spanish governments. The government has instigated anti-crisis measures and one of these has been labour reforms, which have affected basic Spanish labour law, the Workers' Statute [Royal Legislative Decree 1/1995, of 24 March $^{1}$ (hereinafter ET)]. These are reforms derived from the decisions and directives issued by the European Union and which have been adopted by the Spanish government. They are socio-labour adjustments driven by the Troika as a response to the financial crisis of the Spanish banks, which has had a significant cost in terms of labour relations.

Said European guidelines have been general but each State has subsequently and progressively assimilated them while considering their own situation. In reality, this implies that the responsibility for these measures is shared less between European (and international) institutions and the Spanish government itself. The guidelines (or pressure) of the European Union and international organisations, such as the International Monetary Fund (IMF) have been involved in labour reforms and the Spanish government has finally shared this policy. Despite this, the reality is demonstrating that the effects of these measures are not what was hoped and the unemployment situation of the Spanish market has not changed. Even still, and despite the difficult adjustment, the IMF continues to believe these changes are insufficient and that Spain must continue with labour reforms.

These reforms have resulted in a profound transformation of labour relations, with collective bargaining means losing prominence. This signifies that the organisational and discontinuance power of companies has been strengthened with these reforms. It is a frontal change of direction, given that the

${ }^{1}$ Estatuto de los Trabajadores [Real Decreto-Legislativo 1/1995, de 24 de marzo]. 
Constitution considers trade unions as constitutionally relevant subjects and it recognises their right to union freedom and action (art. 7 and 28.1) (TC ${ }^{2}$ Ruling 281/2005, of 7 November). This guideline has directed changes towards the reduction of salaries, the priority of collective company bargaining against sectorial agreements, the facility to substantially modify work contracts, the introduction of an extraordinary permanent contract with lower compensation costs, and the reduction of severance pay.

The last reform took place in 2012 and was carried out by Royal Decree 3/2012, of 10 February 2012, and it was subsequently legally ratified (Law 3/2012, of 6 July 2012, on Urgent Measures for Labour Reform ${ }^{3}$ ). This reform was a step forward in the process of labour reforms. It has attempted to, without managing to do so, stimulate the creation of employment, correct its temporary nature, and contribute to the improvement of the Spanish economy. The purpose of the reform was to generate employment and contain collective dismissals in order to reduce Spain's high rate of unemployment, which is the highest in the European Union, and which has progressively increased despite reforms in the years 2010, 2011 and 2012. Currently, the unemployment rate stands at around $22.85 \%$, with almost $50 \%$ of those workers under 25 years old, while temporary work in Spain represents $25 \%$ in comparison with the European average of $14 \%$. As such, and in order to combat this situation, drastic labour cuts were carried out, being identified as a factor for improving business productivity and the general economy, in the belief that the removal of labour rigidity could remedy unemployment and create jobs.

Additionally, it must be said that this reform is not external to its precedents. There is a clear, central thread based on international and European Union directives. The reform issues are the same, but the 2012 reform was of greater depth, particularly affecting the reduction of severance pay and the weakening of collective bargaining mechanisms by increasing the unilateral decision power of the employer. This is despite the guideline itself, in its preamble, alluding to its intention to search for balanced reform. On the contrary, the direct effects of the reform have been the increase of the individuation of labour relations and the creation of new conditions of insecurity, which can also affect the principle of dignified employment, inspired by the International Labour Organisation (ILO).

The reforms have included the European Union's notion of flexicurity. This is one of its essential objectives. Despite the generic nature of this concept and the imprecise nature of its content, the reform aims to combine elements of labour flexibility and security in employment, without achieving the desired balance. It provides companies with more flexibility, encouraging the modification of contracts and enabling collective bargaining to adapt to the economic reality of the company. Flexibility is conceived when both entering and exiting the labour market. In other words, it facilitates entry to the market with new contracts and it facilitates the possibility of companies with economic problems dismissing employees for less money via lower severance pay. Furthermore, and on the other hand, it aims to encourage employment by improving labour intermediation and professional training. This is combined with elements of security such as the right to a paid training permit, conditional to a year of service in the company. Certain rights to the conciliation of family and work life are also reformed, bearing in mind the productive and organisational needs of companies.

After two years of application, the balance is the considerable decrease of compensation costs for modifications and dismissals, which is applied equally to small and large companies. It is simpler to modify and reduce working conditions and apply labour flexibility in companies. However, the number of disputes has increased considerably and this has resulted in an increase in claims in social courts, giving rise to a pronouncement of the nullity of business measures, in addition to contradictory legal rulings that generate, in certain cases, legal uncertainty.

These measures were adopted without social dialogue with trade unions and business associations. In recent years, social dialogue has deteriorated. This has undoubtedly been a significant effect derived from the crisis and the Spanish government has intervened without considering social agents. The only exception can be found in the scope of Social Security, where the government increased the retirement age from 65 to 67 years old in agreement with trade unions (agreement signed 2 February 2011). However, this agreement has not been reproduced in the labour sector, given that the 2010 reform

\footnotetext{
${ }^{2}$ Tribunal Constitucional (Spanish Constitutional Court).

${ }^{3}$ Ley 3/2012, de 6 de julio de 2012, de medidas urgentes para la Reforma Laboral.
} 
(Royal Decree 10/2010), the collective bargaining reform of 2011 (Royal Decree 7/2011) and the last reform of 2012 were opposed by trade unions.

Before Royal Decree 3/2012, of 10 February, was approved, an agreement between the government and social agents was reached regarding employment and pensions, and this was signed on 25 January 2012 [Inter-Confederation Agreement for Employment and Collective Bargaining (2012-2014) ]. However, this agreement was unobserved with the labour reform of Royal Decree 3/2012. The reforms considered in this law went against the general sense of tripartite agreement between the government and social agents. This was the reason for the second general strike of the crisis, which took place on 29 March 2012, following the general strike of 29 September 2010 against the labour reform of that year. Due to the strike of 2012, CCOO and UGT, majority trade unions, presented claims before the ILO against the Spanish government's reform.

\section{An overview of judicial interpretation: constitutional and judicial control}

In light of the labour reform of 2012, up to three appeals of unconstitutionality have been presented. This gives rise to three sentences of the Constitutional Court (Tribunal Constitucional, hereinafter TC). There are three rulings regarding the labour reform of 2012 that could have been perfectly accumulated to provide a more systematic and clarifying response, without the need to isolate issues and give isolated interpretations.

The first ruling of the TC, of 12 February 2014, referred to the use of the Decree Law formula due to extraordinary reasons of urgent need, without turning to ordinary parliamentary procedure. The TC's Order of 12 February 2014 on the labour reform of 2012 involves the validation of the reform, justifying the actions of the government when legislating due to reasons of urgent need which stem from the country's economic situation. The TC values the existence of extraordinary circumstances and circumstances of urgent need to legislate, enabling the government to legislate by decree instead of commencing ordinary parliamentary process. Despite this, the ruling of the TC of 12 February 2014 involved the particular vote of Judge Fernando Valdés.

Previously, the TC considered the processing of labour reforms via urgent Royal Decree to be unconstitutional. This occurred in 2007, when the method of the decree was not deemed to be justifiable, with the reform of 2002 being annulled, although this had no effect given that said reform was subsequently processed as a draft bill before parliament. TC Ruling 68/2007 ruled the labour reform of the government of Mr José María Aznar (Royal Decree 5/2002) did not respond to a situation of extraordinary urgency and need (a general strike was called due to the reform). Therefore, the fact the omission of the parliamentary process would have caused damage was not accredited. This TC Ruling was definitely a precedent that could have affected the processing of Royal Decree 3/2012, which was later ratified by Law 3/2012. However, the TC did not reach this conclusion in 2014, as it considered this formula to be a legitimate option of legislative policy that does not infringe on fundamental rights or liberties.

Resorting to Decree Law due to urgent reasons was also criticised in the manifesto "Algo estamos haciendo mal" (We are doing something wrong), signed by sixty professors and tutors of public law in February 2014. These professors criticised the approval of more than fifty Decree Laws, ratified by parliament with barely a discussion, in 2012 in addition to the delay of many of them in their processing as laws. Additionally, it must be highlighted that the use of the Decree should be a power of exceptional governance (art. 86 of the Spanish Constitution), especially when the root of its measures may consider significant restrictions to the rights of workers.

The second ruling of the TC happened last July and it is very important as it confirms the constitutionality of the cores of the reform, contesting the appeal of the Parliament of Navarre (TC Ruling of 15 of July 2014). The TC Ruling of 15 July 2014 declares the constitutionality of the labour reform and it deems that the rights of workers, trade-union liberty and the right to collective bargaining are not infringed upon. Despite this, the ruling will involve the individual votes of Judge Fernando Valdés, with whom judges

${ }^{4}$ Acuerdo Interconfederal para el Empleo y la Negociación Colectiva (2012-2014). 
Adela Asua and Luis Ortega, who pertains to the progressive current of the TC, have agreed. In reality, the TC took a stance regarding matters that are also the basis of the appeal put forward by the Socialist Party (Partido Socialista) and the Plural Left (Izquierda Plural). This leaves the basis of this appeal with virtually no substance and it will be resolved under the same interpretative criteria given the current composition of the TC, where the conservative majority carries weight as the political party that sustains the Spanish government. Consequently, the TC has already ruled on two occasions in favour of labour reform, and it must now rule only on the constitutionality of the issues related to flexibility for performing objective and subjective dismissals, or the development of employment regulation records in the public sector, which have been used as cutback methods of the public administration and public companies.

The validation of the TC implies a great polarisation, as it gives priority to the economic and organisational interests of companies and their unilateral will in labour relations, which means reducing the margins of trade-union freedom and collective action. This gives rise to an increase in labour insecurity, moving away from the constitutional consensus that prioritises collective liberties, and altering the impact of action equality at the heart of labour relations. Spain's most representative trade unions, CCOO and UGT, believe labour reform to be an attack on labour rights and collective bargaining (declaration of 20 July 2014). They believe this change of model positions the country in a system that moves away from the democratic model of Employment Law, it takes the country back to Francoism, and that the TC has not come to recognise the influence of fundamental employment rights and trade-union freedom. Trade unions and, without a doubt, socialist and plural-left groups will resort to other international judicial instances. As such, they will try to look for a response to the Spanish legislative measures taken due to crisis. In this regard, the trade unions already reported the reform to the ILO Committee on Freedom of Association on 29 October 2012.

On the other hand, ordinary jurisprudence has had to interpret the most relevant effects of the labour reform. The courts have played an important role, although there are still many questions that have not been clearly resolved. However, as will be discussed later, the essential aspects addressed by the social courts refer to the judicial control of collective dismissals in particular and the assessment of the causes that enable them to be adopted. Social courts continue to interpret regulations from a constitutional perspective, backing collective negotiation and trade-union freedom or the right to work. However, their declarations definitely cannot contradict the sense of legal reforms. Despite this, in some rulings signs of the corrected interpretation of the reform can be discerned, with a more equal working relationship being sought. From a business point of view, fear of legal correction is generated, especially when clear and unequivocal criteria of application do not exist.

Throughout this document, a collection of the most notable Spanish court rulings that interpret the labour reform will be analysed. As a general reflection, it must be stated that the reforms have involved a considerable increase in the workload of the courts, which have inevitably had to rule on its more controversial aspects. The Labour Chambers of the High Court (Tribunal Supremo, hereinafter TS) and the National Court (Audiencia Nacional, hereinafter AN) have been especially prominent.

\section{Promotion of stable employment and labour contracting}

The central idea of the reform is not temporary hiring, but the promotion of permanent contracts. It has, unsuccessfully, aimed to stop the high levels of insecurity linked to temporary contracts. In this sense, the novelty has been the introduction of a contract promoting permanent employment, named support for entrepreneurs (art. 4.1 of Royal Decree 3/2012). This involves a permanent, full-time contract to which only companies with less than fifty employees can resort. This new, permanent contract is presented as an extraordinary resource but in reality the Spanish business model is comprised of smalland medium-sized businesses that represent around ninety percent, and this converts this contract into an almost general option. The only limit is the impossibility of using this contract if, in the previous six months, the company undertook economic dismissals that were declared as unfair. Along with the possibility of the termination of the contract in the period of one year, the business owner benefits from important fiscal and Social Security deductions if the employee works for at least three years. 
The most conflicting aspect of this contract is the legal provision of an obligatory trial period with a duration of one year. This means introducing an element of a temporary nature to the contract, given the insecurity it generates in the job. Furthermore, it must be noted that termination during the trial period is free and without compensation, which leads to unfair or ad nutum dismissal, along with the limitation of legal control, which is not possible, except of course when fundamental workers' rights are violated (TC Ruling 94/1984, TC Ruling 166/1988, TC Ruling of 18 April 2011). All of this could imply a violation of Convention Number 158 of the ILO. Of course, this would be a new contract that equips permanent workers with temporary employment, without containing this duality in the Spanish job market, which is moving towards greater weight for the temporary. In a nutshell, the contract does not facilitate stability in employment and this kind of contract is subject to a large dose of uncertainty.

The TC has endorsed the support for the entrepreneur's contract with a period of one year, without considering compensation for its termination. This has undoubtedly been one of the most critical points, given that both Spanish law and the ILO's conventions declare the right to justifiably dismiss workers, which may imply an infringement on the rights of the worker. Despite this, the TC believes the contract with this trial period of one year encourages employment, given that its trial makes permanent hiring more attractive and considers the legal limitations to its practical application.

Reform also introduces important changes to certain temporary contracts, making the use of temporary contracts appear more attractive to companies. The considerable economic advantages temporary hiring involves for companies have not been eliminated, so there continues to be incentives for its use. On the other hand, it prevents progress in the generation of conditions of labour stability. In spite of all this, the reform tried to compensate for this situation by applying a maximum limit to temporary employment via the linking of temporary contracts equivalent to twenty-four months of work in a period of thirty months (art. 15.5 of the ET).

Use of the temporary contract has been encouraged for training and learning (art. 11.2 of the ET) in order to promote youth employment. The high rate of youth unemployment in Spain should be mentioned once more. Consequently, the maximum duration of work under this contract has been extended to three years, with the minimum duration being six months. Additionally, the apprentice worker can be hired by the same company or by a different company, meaning that apprentices can be employed for up to six or nine years via successive contracts for their training. In reality, they may be apprentices from sixteen to thirty years old, and permanently if the individual is disabled as there is no age limit for this group. An attempt was made to apply the German system for dual professional training to the Spanish model, given that there is a private interest of companies in training and preparing their employees and, on the other hand, public interest in improving employee qualifications via professional training. As such, the system has important incentive measures, including the reduction of Social Security costs for business by $75 \%$ or even $100 \%$.

The next wager was the part-time contract to enable the creation of employment. In Spain, this contract has had minimum use and to foster its usage, the prohibition on working overtime has been lifted. Previously, overtime could only be worked by full-time, permanent employees. Now, the parttime working day can be increased via overtime, which means companies can hire employees to work more hours without assuming responsibility for permanent labour costs and workers can see their remuneration increased by working more hours and being paid for every hour of work resulting in a salary increase. The problem is that this measure inevitably leads to a halt in permanent hiring. It will create more employment, but not employment that is full-time and permanent, which generates stability with dignified working conditions (art. 12 and 35.2 of the ET). The only limit is that overtime and ordinary part-time contract working hours may not exceed a full-time working day, as this would transfer the part-time contract into a full-time contract (art. 12.4.c. of the ET).

Another contract driven by reforms has been the work-at-home contract, which is now called the more general distance contract (art. 13.1 and 2 of the ET). The aim is to favour new forms of telework due to the impact of new technology. In other words, new forms of work that are not telework in the strictest sense, or that do not provide work activity in a company, although this kind of work is present in the labour world due to the application of new forms of business organisation. 
Professional training measures are also strengthened and the right of workers to training aimed at adaption regarding the modifications operated at work is guaranteed. If modifications are imposed by the business owner, he must provide the employee with a course that enables him to adapt to said changes. These modifications must be reasonable in any case. A training permit with the right to have the job post held is legally configured when modifications to the job post occur, in addition to an annual twenty-four-hour training permit also linked to the job post, which will be improved via collective bargaining.

This is combined with another measure that promotes the creation of employment: the possibility of temporary employment agencies intervening in labour intermediation. Temporary work agencies can act as private, profit-making job agencies, contributing to the creation of employment. However, this involves a formula that aims to increase the number of posts, but which comes at the cost of securing models that hinder labour stability and facilitate the loaning of manpower outside the scope of public placement services.

\section{Internal flexibility measures: adaptation of the collective agreement and modification of work contracts}

In terms of collective bargaining, the priority of the company collective agreement against that of the sector is of particular relevance. The reform tries to adapt working conditions to unexpected economic changes. The application of collective agreement, without limits, is a priority and it refers to important conditions such as salary, working hours, holidays, professional qualification, and types of contracts. As such, collective agreement is placed at the service of business interests.

The theory of the priority of company collective agreement has been endorsed by the TC Ruling of July 2014, ratifying the loss of power of collective bargaining. The TC believes this option is valid to the extent that, constitutionally, there is no predetermined collective bargaining model. This is a direct blow to the traditional structure of Spanish collective negotiation, arising from the constitutional model of 1978, which is based on collective labour relations. Social dialogue has configured a sectorial structure of collective bargaining that drives negotiation in the lower area of the sector and which has enabled the expansion of the coverage of workers, which reached $90 \%$ of the active population in 2012 but which is now decreasing. There is no doubt that in the work environment, trade unions have less bargaining power and this model understands this is a change in general influence. In Spain, almost $90 \%$ of companies have less than ten employees. With this in mind, a sector agreement has been confirmed that cannot contemplate minimum obligatory salaries for companies (AN Ruling 95/2012, of 10 September).

The diminishment of collective bargaining coverage is due to another important change: the limitation of the ultra-activity of collective agreements. Before the reform, when a collective agreement completed its agreed duration period, it continued to be applicable until the following negotiation. Currently, ultra-activity is not unlimited, instead, it is restricted to two years as a means of facilitating the adaptation of working conditions (art. 84.2 of the ET). There is no doubt that the original rule of ultra-activity had the benefit of the broad subjective extension of collective agreements and the stability of a regulatory framework that generated legal security, and which could always adapt to structural negotiation in the sector. Therefore, another effect is evident: the breaking up of collective bargaining, disregarding the Second Agreement for employment and negotiation for the years 2012-2014, signed on 25 January 2012.

The next change affects the need to cut salaries and this has occurred via the possibility of removing collective agreements (art. 82.3 of the ET). It is a measure designed for any kind of working condition, but which has been used especially to reduce salaries. Companies must claim business reasons, so economic, technical, productive and organisational reasons have been made more flexible to enable it. The causal factor is the existence of a "negative economic situation, in cases such as the existence of actual or anticipated losses, or the persistent decrease of income or sales."

The only limit is the need for agreement with workers' representatives, meaning the unilateral decision of the business owner is not possible, unlike with modifications and collective dismissals. 
The main source of conflict can be found here, given that the reform aims to avoid the obstruction of negotiation by considering the need for collective agreements to anticipate bargaining conflict resolution procedures and, finally, the obligatory intervention of arbitration, which falls upon the National Advisory Commission on Collective Agreements (Comisión Consultiva Nacional de Convenios Colectivos, the CCNCC), which depends on the Ministry of Employment, or autonomous institutions, in which representatives of the public administration and social agents are present. In this issue, the TC understands that obligatory arbitration before the CCNCC is an efficient mechanism in the adaptation of labour conditions to adverse company circumstances, given that it enables subsequent obstructions in negotiations regarding salary reductions to be avoided. The TC highlights as a guarantee the need for business reasons, meaning economic, technical, organisational or productive reasons, to effectively coincide.

The TC believes this does not infringe upon the constitutional right to collective autonomy, as business owners and trade unions form a part of this organisation. However, the problem is that the Government is present as a third party actor in this organisation, and it decides in the event of disagreement. This is the sensitive area, which may violate the right to collective autonomy. This means a collective agreement may be disregarded with the vote of the public authorities in an administrative organisation, affecting the principle of voluntary nature. Additionally, the TC has come to understand that the setting of salaries and, in general, the content of the labour relationship corresponds to the free autonomy of workers and the business owner, without the interference of the public authorities (TC Ruling 31/1984, of 7 March, and TC Ruling 17/1986, of 4 February).

The TC ruled on the reduction of civil servant salaries, without considering it unconstitutional, as it was deemed not to violate the right to collective bargaining given it was a legally anticipated measure in accordance with the extraordinary economic circumstances of the country. Thus, the principle of normative hierarchy prevailed (TC Ruling 85/2001, of 7 June). Despite this, Spanish trade unions presented a complaint to the ILO, along with Greek and Portuguese trade unions, stating that this was an unusual solution, giving the problem of social cuts an international dimension. However the ILO's Committee on Freedom of Association ruled that international treaties ratified by Spain were not infringed upon (ILO Agreements 87, 98, 151 and 154). In the scope of public employment, unrest increased considerably, giving rise to a general strike in the public sector, seconded by the most representative trade unions, a conflict that was also linked to the removal of the civil servant bonus in 2012.

Within internal flexibility, new possibilities for the substantial modification of the work contract are noteworthy. These are not considered negotiated measures, but they may be implemented via the unilateral choice of the company in order to adapt labour relations for business reasons. As such, the possibility of the irregular distribution of the working day stands out (art. 34.2 of the ET), which may be organised irregularly by collective agreement, but in the absence of agreement the business owner may apply $5 \%$ by means of unilateral decision. Likewise, the possibility of reducing the working day has been enabled (art. 48 of the ET) as a temporary measure to avoid collective dismissals, hence its close link to procedures of suspension and termination of working conditions.

Modifications that enable contracts to adapt to the needs of companies have been channelled by three internal flexibility measures, namely functional mobility, geographical mobility and the substantial modification of working conditions. All of these stem from the need for business reason, generally economic, as a common denominator, the rigor of which has been reduced with reform, making it a much simpler and more effective measure. This enables an intense modification of the conditions agreed in collective agreements, subjecting the business owner to a consultation procedure which, once observed, will apply the measure without the need for agreement with employees (art. 41 of the ET). Likewise, modification is now permitted in reference to the employee remuneration system, now including salary, providing an additional way to reduce wages and salary costs. The AN understands that this modification channel is a response to difficult company situations, which is to say, it is a preventive measure and an alternative to economic dismissals. In these cases, the representatives of workers must observe constructive conduct during the bargaining process, especially when the company sufficiently proves the existence of economic reasons (AN Ruling 61/2012, of 28 May 2012). 


\section{The external flexibility of the work contract: adjustment by means of collective dismissals}

Collective or individual dismissals in small companies due to economic reasons has been a way of reducing fixed labour costs. The adjustment was important as it made the regulation of dismissal noticeably more flexible. This provided companies with the resource of collective dismissals. Therefore, many companies unjustifiably postponed dismissal processes prior to the reform in order to benefit from the new system, although in these cases the AN declared the nullity of the dismissals due to non-compliance with transitory law (AN Ruling of 25 June 2012 and 28 September 2012).

The action of the social courts regarding collective dismissals has been particularly important and, in many cases, it has ruled on controversial aspects of the interpretation of the reform. The AN in particular, more than the social courts, is interpreting the reform. The AN has been leading the way with more coherent and uniform doctrine in its rulings. Despite this, the rulings of the social courts and the AN are setting the interpretative criteria of the more polemical aspects of the reform.

Greater flexibility regarding collective dismissal has been possible thanks to the revision of business reasons, mainly economic, which can be seen with less accuracy. This is because economic reason can be presumed to concur when a persistent decrease in the level of income or sales over the course of three consecutive quarters exists, without the company having to demonstrate this as the results justify the reasonableness of the decision to favour competitiveness (art. 51 of the ET). Despite this, and being more flexible, the causal nature of dismissal is maintained. Special measures have even been taken in the civil service in order to facilitate dismissal. Specifically, considering the existence of a situation of unexpected and persistent (for three consecutive quarters) budgetary insufficiency as a reason for collective dismissals for the financing of public services. It has generated great conflict in this area, as mentioned previously.

The social courts understand that judges may assess the existence of the legality of the reason, as well as its reasonableness, and the judge may evaluate if the dismissal is proportional (Social Court Ruling of 20 December 2013). This implies justifying the dismissal, accrediting its functionality and rationality with regards to tackling the company's needs. The AN has begun to revise the causality and legality in its rulings, which enables legal control (AN Ruling of 21 November 2012). Despite the reform that makes dismissals more dynamic, the courts have continued to maintain the requirement of justified dismissal. The company must prove the dismissal will contribute to an improvement of the economic situation in the future. As such, the mere concurrence of a negative economic situation is not sufficient when a persistent decrease of income over the course of three consecutive quarters exists. Therefore, legal control over the reasons for dismissal is not completely eliminated, given that the dismissal must be justified (vid. art. 158 ILO Convention). The courts can continue to understand the rationality of the business measure and dismissal is not an absolute or arbitrary right of the company.

Despite this, there is no doubt that justification has been relaxed, considering it is enough to say how many dismissals are to be carried out and to justify the negative development of the company with the relevant documents. It would not be necessary to confirm that the dismissals will contribute to the survival of the company or the overcoming of the company crisis (Social Court Ruling of 20 December 2013, AN Ruling of 21 November 2012, and TS ${ }^{5}$ of Galicia Ruling of 6 July 2012). These rulings, in reality, came to encompass an interpretation of the social courts prior to the reform itself, which understood that it was enough to accredit the existence of continued and substantial losses (Social Court Ruling of 11 June 2008).

Due to Directive 98/58/CE of 20 July 1998, the consultation or collective bargaining period has been maintained. However, it does not require agreement with representatives and the requirement of administrative authorisation to be able to apply the dismissals has disappeared. The consultation period may finish with agreement and, in its absence, the business owner will adopt the measure he deems appropriate, and the labour authority must be informed of this. The suppression of administrative authorisation is the most important measure, and it is substituted by a simple form of communication with the labour authority. The TC still has not taken a stance with regards to this issue, considering it must still

${ }^{5}$ Tribunal Superior (Regional High Court). 
resolve the third appeal of unconstitutionality. However, authorisation was a requirement for dismissals due to crisis, valid in our legal system since 1944, but this authorisation, in reality, was an act of legal control and the corresponding administrations had not assumed responsibility for ruling in the event of disagreement. Additionally, Spain was one of the last European countries to maintain this kind of authorisation in its legislation.

The courts have interpreted controversial issues regarding business restructuring processes. Without a doubt, another essential theme is that of negotiating on collective dismissals. Spanish legislation and direct European legislation refer to a general bargaining concept, in addition to the observance of the duty of good faith in the consultation phase. The duty of good faith negotiation declares a desire to initiate an authentic bargaining process. Simply informing of dismissals before finalising the consultation period is not enough, given that it would demonstrate in reality that there is no attempt to negotiate. Therefore, good faith is presented as a general validity requirement for the dismissal procedure (AN Ruling of 15 October 2012).

In collective dismissals, it is necessary to prove the reason for dismissal and to comply with the company's obligations of documentation and information to workers. The essential requirement of the negotiation is the delivery of information by the company. Therefore, all the information referring to the economic situation of the company must be provided, which will enable the justification of the poor economic situation (TS of Madrid Ruling of 22 June, 30 May and 11 July 2012). Additionally, the company must supply information about the professional classification of the employees affected by collective dismissal (TS of Catalonia Ruling of 23 May 2012). This would be a basic element in the consultation period (art. 51.2 of the ET). What's more, the company must communicate the criteria for determining the employees affected by dismissal at the start of the consultation period (TS of Madrid Ruling of 25 June 2012). Therefore, the courts can declare the nullity of dismissal by understanding that the company does not sufficiently comply with its duty to inform the representatives of workers.

When bargaining, the company has diverse communication options with workers' representatives. Consultations can be performed with trade union representatives or unions with workers' commissions can be turned to directly, doing without trade unions. The important element is for consultation and negotiation to occur, and the law opts for trade-union representation but this does not mean tradeunion representation is always necessary (art. 51 of the ET) [AN Ruling of 28 September 2012]. In spite of this, bargaining without trade unions could pose practical problems. The negotiation commission formed by workers, without the presence of trade unions, may not contest collective dismissals (art. 51.2 and 124 of the Law Regulating the Social Courts). From a procedural point of view, this is not permitted legally, although in some cases this possibility has been favourably interpreted (TS of Catalonia Ruling of 23 May 2012). This understands that these workers would act, in any case, as labour representatives for the purpose of being able to exercise the fundamental right to the effective protection of the court (art. 24 of the Spanish Constitution).

The other issue is what companies or organisations are authorised to negotiate. If the dismissal process is started, it must be processed in the scope of the company, as indicated in Directive 98/59 on collective dismissals and art. 51 of the ET. However, the law does not refer to the possibility of collective dismissals in business groups. The AN Ruling of 28 September 2012 backs the bargaining legitimisation of the group with the view to facilitating a unique procedure which enables a homogeneous result. This is due to the fact the group is the real business owner (in this sense: AN Ruling of 26 July 2012 and TS of Extremadura Ruling of 26 July 2012). Therefore, the fragmentation of dismissal is avoided, under penalty of nullity, if the real business owner, which is the group, avoids formally presenting itself, as occurs in legal fraud (TS of Catalonia Ruling off 23 May 2012). Economic reason must affect every business in the group and not just one individually considered business (AN Ruling of 28 September 2012). On the other hand, consultations must be formalised with the totality of the company and not the work centre (AN Ruling of 25 June 2012). Effectively, negotiations can be carried out per work centre, but always with an overview and by using the general situation of the company as a reference (AN Ruling of 25 July 2012). Royal Decree 1482/2012, of 29 October, enables different bargaining in each work centre, but the courts understand that these negotiations may not lose the general perspective of the company. 
Apart from collective economic dismissal, labour reform has been responsible for reducing the costs of common dismissal. It has noticeably reduced the amount of compensation from forty to five days' salary per year of service with a limit of forty-two monthly payments, and it has planned a new compensatory module of thirty-three days with a limit of twenty-four months (art. 56.1 of the ET). In this regard, the TC Order of February 2014 endorsed the constitutionality of the measure, in addition to the limiting of back pay in cases of readmission. This implies limiting the economic amount the worker may yield from the moment he is dismissed until there is a final judicial decision. Currently, resorting to back pay has become a truly residual note. 